\title{
Enhancement of Biogas Production from Sewage Sludge with the Addition of Geobacillus sp. Strain AT1 Culture
}

\author{
MD SHOHIDULLAH MIAH ${ }^{1,2}$, CHIKA TADA $^{1}$, and SHIGEKI SAWAYAMA ${ }^{1 *}$ \\ ${ }^{1}$ Biomass Group, Energy Technology Research Institute, National Institute of Advanced Industrial Science \\ and Technology / 16-1 Onogawa, Tsukuba, Ibaraki 305-8569, Japan \\ ${ }^{2}$ Post-doctoral Fellow, Japan Society for the Promotion Science (JSPS)
}

\begin{abstract}
We investigated the enhancement of biogas production from anaerobic digestion of sewage sludge with the addition of an aerobic thermophilic bacterial culture of Geobacillus sp. strain AT1. Biogas production was significantly enhanced by the $2 \mathrm{ml}$ addition of stationary-growth-phase culture (24h) of strain AT1 to $38 \mathrm{ml}$ methanogenic sludge. Strain AT1 grew aerobically in $\mathbf{F}-\mathbf{J X}$ synthetic medium, and optimum growth occurred at pH 7.0 and $65^{\circ} \mathrm{C}$ with shaking at $140 \mathrm{rpm}$. The optimum temperature for protease activity in the strain AT1 culture was around $65^{\circ} \mathrm{C}$ in the presence of $2 \mathrm{mM}$ $\mathrm{CaCl}_{2}$, where relative protease activity reached $210 \%$ compared with that at $35{ }^{\circ} \mathrm{C}$ without $\mathrm{CaCl}_{2}$. Protease activity was stable from 35 to $65{ }^{\circ} \mathrm{C}$, but rapidly decreased within $30 \mathrm{~min}$ incubation at $85^{\circ} \mathrm{C}$. A protease inhibitor mixture (AEBSF, bestatin, E-64, EDTA, and pepstatin) inhibited the biogas enhancement by the strain AT1 culture. Methane production was enhanced by 2.1 times with the addition of the strain AT1 culture compared with the addition of $F-J X$ medium, and was enhanced by 2.8 times with the additions of authentic protease and serine protease $S$. These results suggest that the enhancement of biogas production from anaerobic digestion of sewage sludge was caused by the protease activity of aerobic thermophilic Geobacillus sp. strain AT1.
\end{abstract}

Key words: anaerobic digestion, aerobic thermophilic bacteria, protease, biogas, methane, Geobacillus

\section{INTRODUCTION}

Vast amounts of sewage sludge are released in the aerobic treatment of wastewater. To prevent water pollution, land filling and ocean dumping of sewage sludge are now regulated. Hygienic, efficient, and energy-saving treatment technology for sewage sludge is required. Sewage sludge contains high amounts of organic matter which could be reusable as a substrate for anaerobic digestion. ${ }^{1}$ Thermochemical and biological pretreatment methods have been studied to improve the low degradation ratio and rate of conventional anaerobic digestion of sewage sludge..$^{2-4)}$

Aerobic thermophilic (AT) and anaerobic mesophilic treatments of sludge have been reported in terms of pathogen reduction, vector attraction reduction, volatile solids reduction, gas production, and product sludge dewaterability. ${ }^{5}$ Solubilization of organic sludge by AT bacteria as a pretreatment for anaerobic digestion was studied.4) We have reported that AT bacteria can be grown with sewage sludge or anaerobically digested sewage sludge, and that the addition of a small amount of AT bacterial sludge enhanced biogas production and volatile solids reduction. ${ }^{6)}$ 
AT bacteria can hydrolyze organic waste. The microbial enzymatic activity has a significant role in the decomposition of organic compounds under anaerobic conditions. ${ }^{8)}$ Protease activity varies from species to species and depends on the environmental adaptation of organisms.9) Microbial enzymatic hydrolysis of organic wastes is an attractive topic in the reuse of organic wastes. The biodegradation of sewage sludge using bacterial enzymes could be useful for the improvement of biogasification.

Microorganisms are the most important sources of enzyme production. ${ }^{10)}$ Proteases are produced by a wide range of microorganisms, including bacteria, moulds, and yeasts. Thermophilic bacteria are widely spread in thermal environments. ${ }^{11}$ Currently a large proportion of commercially available proteases are derived from Bacillus sp. ${ }^{12)}$ Many bacteria belonging to the genus Bacillus and Geobacillus excrete large amounts of enzymes into the culture medium. ${ }^{13)}$ Thermophilic bacterial protease could be useful for the enhancement of biodegradation of sewage sludge.

In this study, we investigated the growth characteristics of Geobacillus sp. strain AT1 and its protease activity to reveal the mechanism of the enhancement of biogas production from the anaerobic digestion of sewage sludge with the addition of the strain AT1 culture.

\section{MATERIALS AND METHODS}

\section{Cultivation of strain AT1 Geobacillus} sp. strain AT1 has been recently isolated from aerobically and thermophilically acclimatized sludge. Strain AT1 was grown in $100 \mathrm{ml} \mathrm{F}$-JX synthetic medium in a $250 \mathrm{ml}$ flask. The bioreactor was maintained at $65{ }^{\circ} \mathrm{C}$ with shaking at $140 \mathrm{rpm}$. The F-JX medium contained yeast extract $0.1 \% \quad(\mathrm{w} / \mathrm{v})$ and trypticase peptone $0.1 \%(\mathrm{w} / \mathrm{v}) .{ }^{14)}$ The $\mathrm{pH}$ of the F-JX medium was adjusted to 7.0.

Growth conditions of strain AT1 We investigated the growth of strain AT1 in autoclaved $\mathrm{F}$-JX medium over a $\mathrm{pH}$ range of 5 to 9.5. The $\mathrm{pH}$ was adjusted with $\mathrm{HCl}$ and $\mathrm{NaOH}$. The bacterial culture was maintained at $65^{\circ} \mathrm{C}$ with aerobic shaking at $140 \mathrm{rpm}$. The growth of strain AT1 was measured at 660 $\mathrm{nm}$ by a spectrophotometer at $24 \mathrm{~h}$ of culture.

The growth of strain AT1 was measured in F-JX medium at temperatures of $56,58,60$, $64,66,68$, and $72{ }^{\circ} \mathrm{C}$ under anaerobic and aerobic conditions. The anaerobic reactor was purged with nitrogen gas to eliminate air. Both reactors were maintained at $65{ }^{\circ} \mathrm{C}$ with shaking at $140 \mathrm{rpm}$. All growth tests were done in triplicate.

Protease activity Protease activity was determined by the modified method of Ghorbel et al. (2003). ${ }^{15)}$ The culture medium was centrifuged, and $0.5 \mathrm{ml}$ of the supernatant was mixed with $0.5 \mathrm{ml}$ of 100 $\mathrm{mM}$ Tris $-\mathrm{HCl}(\mathrm{pH} 8.0)$ containing $1 \%$ casein. The mixture was incubated for $15 \mathrm{~min}$ at 60 ${ }^{\circ} \mathrm{C}$. The reaction was terminated by the addition of $0.5 \mathrm{ml}$ trichloroacetic acid $(20 \%$, w/v). The mixture was kept at room temperature for $15 \mathrm{~min}$ and then centrifuged at $13,000 \mathrm{rpm}$ for $15 \mathrm{~min}$. The absorbance of the supernatant was measured at $280 \mathrm{~nm}$. A standard curve was prepared by using solutions of $0-50 \mathrm{mg} / l$ tyrosine. One unit of protease activity was defined as the amount of enzyme corresponding to the absorbance of $1 \mu \mathrm{g} / \mathrm{m} l$ tyrosine.

Protease activity of $160 \mathrm{units} / \mathrm{ml}$ measured at $35^{\circ} \mathrm{C}$ and $\mathrm{pH} 7.0$ without $\mathrm{CaCl}_{2}$ using the $24 \mathrm{~h}$ culture of strain AT1 was defined as $100 \%$ activity. Protease activity was measured with or without $2 \mathrm{mM} \mathrm{CaCl}$. The effect of incubating temperature of protease activity was examined at temperatures of 15 , $35,45,55,65$, and $75^{\circ} \mathrm{C}$. The $\mathrm{pH}$ was adjusted with $\mathrm{HCl}$ and $\mathrm{NaOH}$. The stability of protease at high temperature $(35,65$, and 85 ${ }^{\circ} \mathrm{C}$ ) was determined with incubation periods of 0 to $120 \mathrm{~min}$ at 15 - $\mathrm{min}$ intervals.

Effect on anaerobic digestion To a 100$\mathrm{m} l$ glass reactor we added $2 \mathrm{~m} l$ of AT1 culture and $38 \mathrm{~m} l$ of methanogenic sludge. Methanogenic sludge was sampled from an anaerobic digestion tank treating sewage sludge (primary and waste activated sludges) in a communal wastewater treatment plant (Ibaraki Prefecture, Japan). The AT1 was grown at $\mathrm{pH} 7.0$ and $65^{\circ} \mathrm{C}$ with shaking 140 rpm. The strain AT1 cultures at different 
growth phases of $6,12,24$, and $48 \mathrm{~h}$ were added to the methanogenic sludge. F-JX medium $(2 \mathrm{~m} l)$ without AT1 was added to methanogenic sludge as control. Another reactor was filled with only methanogenic sludge $(38 \mathrm{~m} l)$ and distilled water $(2 \mathrm{ml})$. Each glass reactor was capped with a natural rubber sleeve stopper and then sealed with a thin aluminum cover-cap to impose anaerobic conditions. Air in the reactors was replaced with nitrogen gas. The reactors were then placed in a thermostat at $35 \pm 1{ }^{\circ} \mathrm{C}$. All the activity tests were carried out in triplicate. Biogas production and volatile solids (VS) reduction in the bioreactors were measured. The experiment was terminated after 20 days, when biogas production had stopped.

Effect of protease inhibitor We studied the effect of a protease inhibitor mixture containing AEBSF hydrochloride (final concentration $200 \mu \mathrm{mol} / l$ ), bestatin (17 $\mu$ $\mathrm{mol} / l), \quad \mathrm{E}-64$ protease inhibitor $(2 \mu \mathrm{mol} / l)$, EDTA disodium $(850 \mu \mathrm{mol} / l)$, and pepstatin A $(20 \mu \mathrm{mol} / l)$. The inhibitor mixture was dissolved in $1 \mathrm{~m} l$ dimethyl sulfoxide (DMSO) and $4 \mathrm{ml}$ distilled water. The active volume of the bioreactors was $40 \mathrm{ml}$, made up of methanogenic sludge $37 \mathrm{ml}$, AT1 culture 2 $\mathrm{ml}$, and inhibitor mixture solution $1 \mathrm{ml}$. F-JX medium without bacteria, strain AT1 + DMSO, autoclaved strain AT1 culture, and strain AT1 culture alone were also added to the methanogenic sludge as controls. During anaerobic digestion, biogas production and methane concentration were measured as above.

\section{Effect of authentic proteases Authentic} protease (Wako, Tokyo, Japan) was diluted with distilled water, and serine protease $\mathrm{S}$ (Sigma-Aldrich, St. Louis, Missouri, USA) was dissolved in $25 \mathrm{mM}$ Tris- $\mathrm{HCl}(\mathrm{pH}$ 7.6) with $40 \%$ ethanol. The authentic protease (final concentration 20 units $/ \mathrm{ml}$ ) and serine protease $S$ (20 units $/ \mathrm{m} l$ ) were added $(2 \mathrm{ml}$ total) to the methanogenic sludge $(38 \mathrm{ml})$. The AT1 culture $(2 \mathrm{ml}$, final concentration of protease activity 8 units $/ \mathrm{m} l$ ) was added to the methanogenic sludge $(38 \mathrm{ml})$. As a control, (final concentration 20 units $/ \mathrm{ml}$ ) $2 \mathrm{ml}$ of 25 $\mathrm{mM}$ Tris- $\mathrm{HCl}(\mathrm{pH} 7.6)$ with $40 \%$ ethanol was added to the methanogenic sludge $(38 \mathrm{ml})$.

Analysis The volatile solids (VS) content of the sludge in the reactor was measured on operational day 0 and at the end of the experiment. The VS content was determined by heating at $105^{\circ} \mathrm{C}$ for $24 \mathrm{~h}$ and after heating at $600{ }^{\circ} \mathrm{C}$ for $1 \mathrm{~h}$. The biogas composition was determined by gas chromatograph (model GC-12A, Shimadzu, Kyoto, Japan) with a Porapak Q column (Shinwakakou, Kyoto, Japan) at $90^{\circ} \mathrm{C}$.

\section{RESULTS AND DISCUSSION}

\section{Enhancement of biogas production}

Figure 1 shows the biogas production with the addition of different growth phases of strain AT1 culture to the methanogenic sludge. The biogas production from the anaerobic digestion of sewage sludge was significantly improved with the addition of $5 \%(\mathrm{v} / \mathrm{v})$ AT1 culture. AT bacteria hydrolyze sludge with extracellular enzymes. ${ }^{16,}{ }^{17)}$ The biogas production was enhanced $95 \%$ by the addition of the stationary growth phase (24

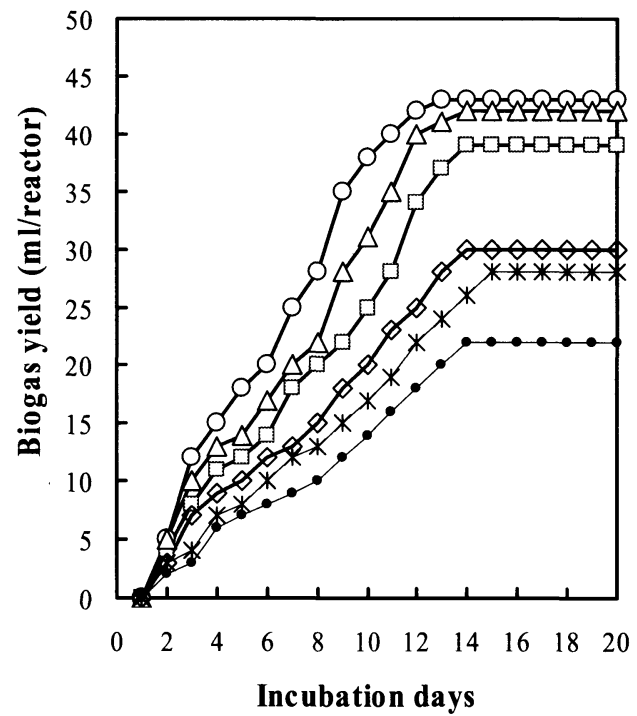

$$
\begin{aligned}
& \multimap-48 \mathrm{~h} \rightarrow-24 \mathrm{~h} \rightarrow 12 \mathrm{~h} \\
& \neg 6 \mathrm{~h} \rightarrow \mathrm{W}-\mathrm{FX} \rightarrow \mathrm{DW}
\end{aligned}
$$

Fig. 1 Cumulative biogas production with the addition of different growth phases of Geobacillus sp. strain AT1 culture into the methanogenic sludge. The bioreactor was incubated at $35^{\circ} \mathrm{C}$ 
h) culture of strain AT1 compared with the distilled water addition. We assume that strain AT1 excreted the optimum amount of enzymes during the 24-h incubation period. Another Bacillus sp. excreted the optimal amount of protease in the culture medium during its post-exponential and stationary growth phases. ${ }^{18)}$ Hydrolysis activity in the anaerobic digestion is mainly influenced by the bacterial enzymatic activity. ${ }^{19)}$ The enhancement of the biogas production with the addition of strain AT1 culture could be caused by the enzymatic activity excreted from strain AT1 cells. There were no marked differences in biogas production among the addition of F-JX medium without strain AT1 cells and with 6 -h culture of strain AT1 to the methanogenic sludge.

Table 1 shows the VS reduction with the addition of strain AT1 culture to the methanogenic sludge. The highest VS reduction was $15 \%$ when 12 - $\mathrm{h}$ and 24 -h AT1 culture was added. The methane gas concentration ranged from $60 \%$ to $63 \%$, which were not significantly different. The enhancement of biogas production and VS reduction were correlated.

Growth of strain AT1 Geobacillus sp. strain AT1 was isolated in our laboratory from AT seed sludge taken from sewage sludge. Isolated strain AT1 grew well in F-JX culture medium. Strain AT1 grew well at temperatures ranging from 56 to $70{ }^{\circ} \mathrm{C}$ (Fig. 2). The optimum growth temperature of AT1 was $65-67{ }^{\circ} \mathrm{C}$. Figure 3 shows the growth of strain AT1 at different $\mathrm{pH}$ levels. The optimum growth (cell density, $\mathrm{OD}_{660}=0.55$ ) occurred at $\mathrm{pH}$ 7.0-7.5. Strain AT1 could not grow well at either high acidity or high alkalinity.

The growth curves of strain AT1 under aerobic and anaerobic conditions are shown in Fig. 4. Strain AT1 grew well in aerobic conditions, but it could not grow in anaerobic conditions. The optimum growth occurred at 24-h culture under aerobic conditions with shaking.

Protease activity Protease activity at 35 ${ }^{\circ} \mathrm{C}$ and $\mathrm{pH} 7.0$ without $\mathrm{CaCl}_{2}$ using the $24 \mathrm{~h}$ culture of strain AT1 was 160 units/ml and was defined as $100 \%$. The optimum incubating temperature for the protease production in the strain AT1 culture was 65 ${ }^{\circ} \mathrm{C}$ in the presence of $2 \mathrm{mM} \mathrm{CaCl}_{2}$ (Fig. 5). The relative protease activity of strain AT1 increased by $210 \%$ with and $160 \%$ without 2 $\mathrm{mM} \mathrm{CaCl}{ }_{2}$ at $65^{\circ} \mathrm{C}$ compared with that at 35 ${ }^{\circ} \mathrm{C}$. On the other hand, it decreased to $14 \%$ at $35{ }^{\circ} \mathrm{C}$ without $\mathrm{CaCl}_{2}$ (Fig. 5). Ghorbel et al. (2003) reported that $2 \mathrm{mM} \mathrm{CaCl}{ }_{2}$ stimulated protease activity by $500 \%{ }^{15)}$ Mabrouk et al. (1999) optimized the protease production from Bacillus licheniformis by adding $\mathrm{CaCl}_{2}$ to the culture medium. ${ }^{20)}$ The protease activity in the strain AT1 culture was activated by the presence of $2 \mathrm{mM} \mathrm{CaCl}_{2}$.

The protease activity of the strain AT1 culture grown at $65^{\circ} \mathrm{C}$ was higher than that grown at $35^{\circ} \mathrm{C}$ (Fig. 6). Protease activity was rapidly reduced at $85^{\circ} \mathrm{C}$ after $30 \mathrm{~min}$ (Fig. 6). The protease enzyme from $B$. cereus $\mathrm{BG} 1$ was rapidly denatured at $70^{\circ} \mathrm{C}$ after $4 \mathrm{~min}$ of incubation. ${ }^{14)}$ The protease produced by strain AT1 could be a thermostable enzyme.

Table 1 VS reduction with the addition of different incubation periods of strain AT1 culture to the methanogenic sludge

\begin{tabular}{lccc}
\hline $\begin{array}{l}\text { Different incubation periods } \\
\text { of strain AT1 culture }\end{array}$ & $\begin{array}{c}\text { Initial VS } \\
(\%)\end{array}$ & $\begin{array}{c}\text { Final VS } \\
(\%)\end{array}$ & $\begin{array}{c}\text { VS reduction } \\
(\%)\end{array}$ \\
\hline 6 h culture & 0.62 & 0.57 & 8 \\
12 h culture & 0.65 & 0.55 & 15 \\
24 h culture & 0.65 & 0.55 & 15 \\
48 h culture & 0.57 & 0.52 & 9 \\
FJ-X medium & 0.59 & 0.55 & 7 \\
Distilled water & 0.65 & 0.59 & 9 \\
\hline
\end{tabular}




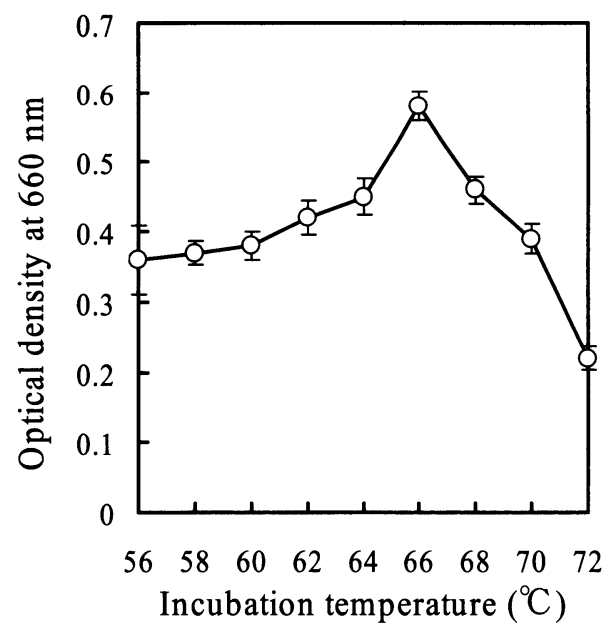

Fig. 2 Growth curve of Geobacillus sp. strain AT1 at different temperatures. The strain AT1 culture was incubated with aerobic shaking. A cell concentration of the AT1 culture was measured by optical density at $660 \mathrm{~nm}$. Bars indicate standard error.

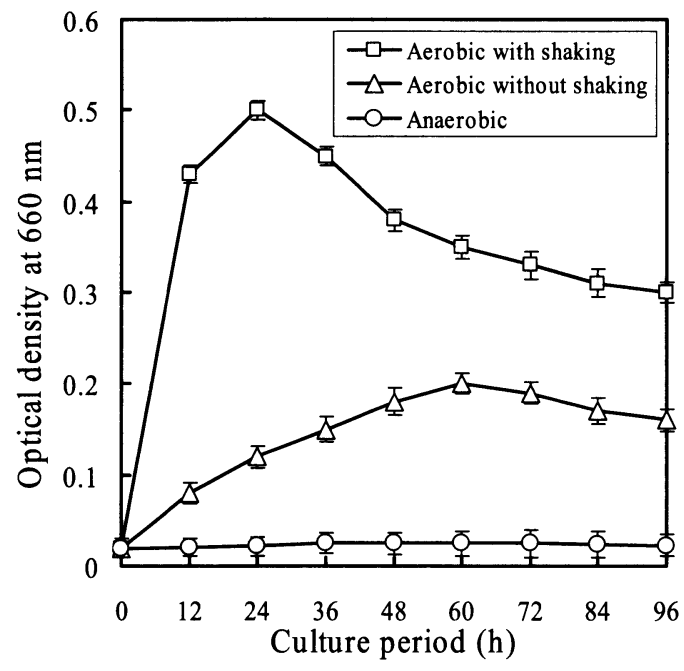

Fig. 4 Growth curve of Geobacillus sp. strain AT1 under anaerobic and aerobic conditions. The strain AT1 culture was incubated at $65^{\circ} \mathrm{C}$. A cell concentration of the AT1 culture was measured by optical density at $660 \mathrm{~nm}$. Bars indicate standard error.

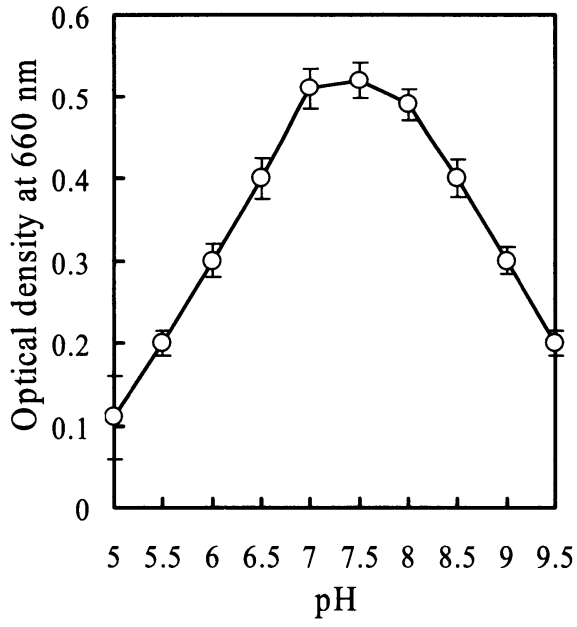

Fig. 3 Growth curve of Geobacillus sp. strain AT1 at different $\mathrm{pH}$. The strain AT1 culture was incubated at $65^{\circ} \mathrm{C}$ with aerobic shaking. A cell concentration of the AT1 culture was measured by optical density at $660 \mathrm{~nm}$. Bars indicate standard error.

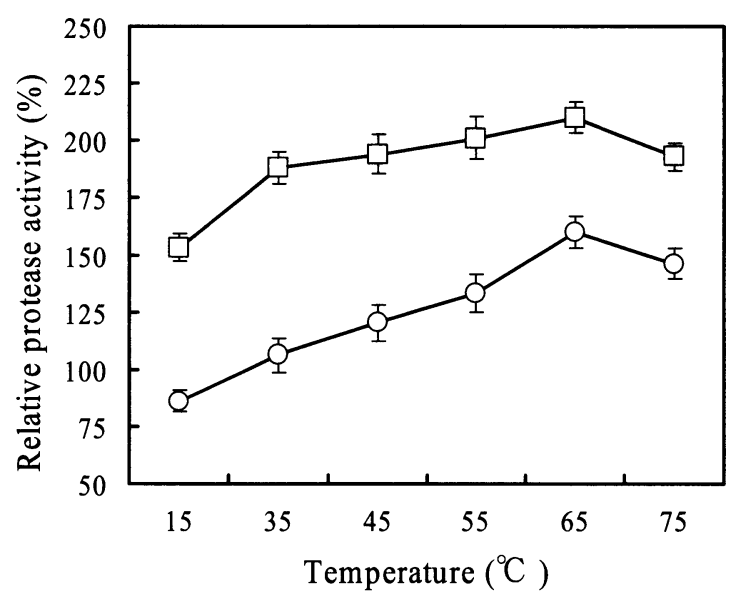

Fig. 5 Change in relative protease activity of Geobacillus sp. strain AT1 culture at different temperatures with or without $2 \mathrm{mM} \mathrm{CaCl}_{2}$. The strain AT1 culture was incubated with aerobic shaking. Symbols: square; with $2 \mathrm{mM} \mathrm{CaCl}$, circle; without $2 \mathrm{mM} \mathrm{CaCl}_{2}$. 
Protease inhibitor The highest volume of methane produced was $32 \mathrm{ml} /$ reactor with the addition of the strain AT1 culture without protease inhibitor. Biogas production was not enhanced with the addition of protease inhibitor mixture and strain AT1 culture (Fig. 7). On the other hand, DMSO (2 $\mu l / 40 \mathrm{~m} l)$ did not inhibit the enhancement of the biogas production with the addition of the strain AT1 culture. These results suggest that the enhancement by strain AT1 was caused by protease activity. The methane composition of the biogas (70\%) was not affected by the protease inhibitor addition.

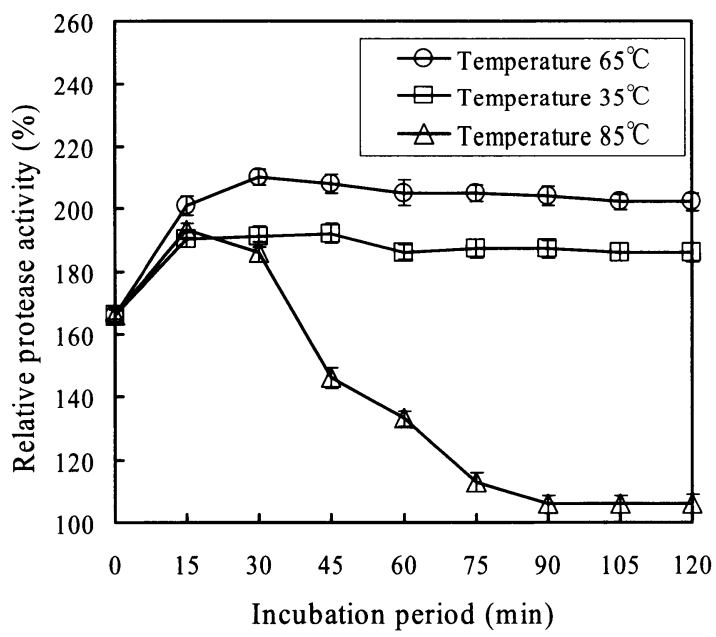

Fig. 6 Change in relative protease activity in Geobacillus sp. strain AT1 culture at different incubating temperature during protease activity measurement with $2 \mathrm{mM} \mathrm{CaCl}_{2}$
Biogas production did not increase with the addition of F-JX medium or of autoclaved strain AT1 culture to the methanogenic sludge. This result indicates that the enzymatic activity of strain AT1 is destroyed at $120^{\circ} \mathrm{C}$. F-JX medium without the strain AT1 cells did not enhance biogas production.

Table 2 shows the VS reduction with the addition of protease inhibitor mixture with the strain AT1 culture to the methanogenic sludge. The highest VS reduction (14\%) occurred with the addition of the strain AT1 culture to the methanogenic sludge. The high VS reduction was directly correlated with the

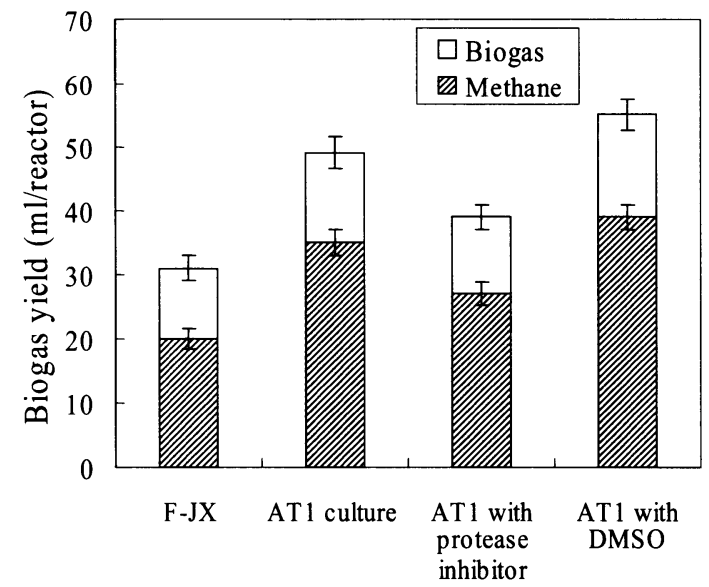

Fig. 7 Biogas yield with the addition of protease inhibitor and strain AT1 culture to the anaerobic digestion of sewage sludge

Table 2 Effect of the addition of protease inhibitor and strain AT1 culture to the methanogenic sludge on the anaerobic digestion

\begin{tabular}{|c|c|c|c|}
\hline Added samples to the methanogenic sludge & $\begin{array}{c}\text { Initial VS } \\
(\%)\end{array}$ & $\begin{array}{c}\text { Final VS } \\
(\%)\end{array}$ & $\begin{array}{c}\text { VS reduction } \\
(\%)\end{array}$ \\
\hline Strain AT1 culture & 0.58 & 0.50 & 14 \\
\hline Strain AT1 culture + Protease inhibitor mixture solution ${ }^{a}$ & 0.63 & 0.58 & 7.9 \\
\hline Strain AT1 culture + $\mathrm{DMSO}^{\mathrm{b})}$ & 0.63 & 0.56 & 11 \\
\hline Autoclaved strain AT1 culture & 0.58 & 0.53 & 8.6 \\
\hline F-JX medium & 0.56 & 0.52 & 7.1 \\
\hline
\end{tabular}

a) Protease inhibitor mixture solution $(1 \mathrm{~m} l$ ) contains AEBSF hydrochloride (final concentration $200 \mu$ mol $/ l$ ), bestatin $(17 \mu \mathrm{mol} / l)$, E-64 protease inhibitor $(2 \mu \mathrm{mol} / l)$, EDTA disodium $(850 \mu \mathrm{mol} / l)$, pepstatin A $(20 \mu \mathrm{mol} / l), 2 \mu l$ dimethyl sulfoxide (DMSO) and distilled water. The active volume of the bioreactors was $40 \mathrm{ml}$, made up of methanogenic sludge $37 \mathrm{ml}$, AT1 culture $2 \mathrm{ml}$, and inhibitor mixture solution $1 \mathrm{ml}$.

b) DMSO $2 \mu l$ was added to the $40 \mathrm{~m} l$ methanogenic sludge. 
relatively high methane production. DMSO did not affect VS reduction. These results suggest that protease activity in the strain AT1 culture improves sludge degradation and methanogenesis.

Effect of authentic protease Biogas production was markedly enhanced with the addition of both authentic protease (50 $\mathrm{m} l /$ reactor) and serine protease $\mathrm{S}$ (48 $\mathrm{m} l /$ reactor) to the methanogenic sludge at a final concentration of 20 units $/ \mathrm{ml}$ (Fig. 8). Methane production was enhanced by 2.1 times with the addition of the strain AT1 culture (final protease activity 8 units $/ \mathrm{ml}$ ) compared with F-JX medium alone, and was enhanced by 2.8 times with the additions of authentic protease and serine protease $\mathrm{S}$ (final protease activity 20 units $/ \mathrm{ml}$ ). Biogas production did not increase with the addition of distilled water or $25 \mathrm{mM}$ Tris- $\mathrm{HCl}$ with $40 \%$ ethanol to the methanogenic sludge. The methane compositions were not different among these treatments. These results suggest that protease can improve sludge degradation and methanogenesis.

We have reported that AT bacteria can be grown with sewage sludge and anaerobically digested sewage sludge, and that AT bacterial sludge enhances degradation and biogas production from anaerobic digestion of

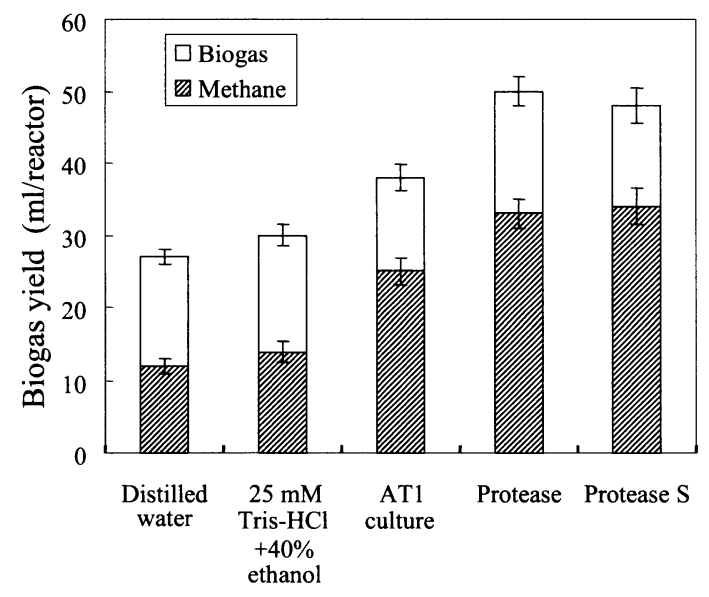

Fig. 8 Biogas yield with the addition of authentic protease or serine protease $S$ and strain AT1 culture to the anaerobic digestion of sewage sludge sewage sludge. ${ }^{6}$ The present results show that this enhancement is caused by protease activity released from Geobacillus sp. We propose that a small addition of AT bacterial sludge to methanogenic sludge will improve biogasification of sewage sludge.

\section{CONCLUSIONS}

The present results suggest that the enhancement of biogas production from anaerobic digestion of sewage sludge was caused by protease activity of thermophilic Geobacillus sp. strain AT1. Strain AT1 grew aerobically in F-JX synthetic medium, and optimum growth occurred at $\mathrm{pH} 7.0$ and $65^{\circ} \mathrm{C}$ with shaking at $140 \mathrm{rpm}$. The relative protease activity in the strain AT1 culture reached $210 \%$ in the presence of $2 \mathrm{mM} \mathrm{CaCl}_{2}$ at $65{ }^{\circ} \mathrm{C}$. The protease activity was stable from 35 to $65^{\circ} \mathrm{C}$, but rapidly decreased within $30 \mathrm{~min}$ of incubation at $85{ }^{\circ} \mathrm{C}$. The protease inhibitor mixture inhibited the biogas enhancement by strain AT1. Methane production was enhanced by 2.1 times with the addition of the strain AT1 culture compared with F-JX medium alone, and was enhanced by 2.8 times with the additions of authentic protease and serine protease $\mathrm{S}$. Addition of a small amount of AT bacteria to methanogenic sludge could improve biogasification of sewage sludge.

\section{REFERENCE}

1 ) Fannin, F. F., Conrad, J. R., Srivastava, V. J., Jerger, D. E., and Chynoweth, D. P.: Anaerobic processes, J. Water Poll. Cont. Fed., 55, 623-632 (1983)

2 ) Haug, R. T.: Sludge processing to optimize digestibility and energy production, J. Water Poll. Control Fed., 49, 1713-1721 (1977)

3 ) Sawayama, S., Inoue S., Yagishita, T., Ogi T., and Yokoyama, S. Y.: Thermochemical liquidization and anaerobic treatment of dewatered sewage sludge, J. Ferment. Bioeng., 79, 300-302 (1995)

4 ) Hasegawa, S., Shiota, N., Katsura, K., and Akashi, A.: Solubilization of organic sludge by thermophilic aerobic bacteria as a pretreatment for anaerobic digestion, Water Sci. Technol., 41, 163- 
$169(2000)$

5 ) Cheunbarn, T. and Pagilla, K. R.: Aerobic thermophilic and anaerobic mesophilic treatment of sludge, J. Environ. Eng. 129, 790- 795 (2000)

6 ) Miah, M. D., Tada, C., Tsukahara, K., Yagishita, T., and Sawayama, S.: Effect of aerobic thermophilic pretreatment of anaerobically digested sewage sludge on anaerobic re-digestion, Proceedings of Asian Waterqual, 20033Q4I05 p1-9 (2003)

7 ) Taguchi, F., Guofu, S., and Guanglei, Z.: Microbial treatment of kitchen refuse with enzyme-producing thermophilic bacteria from Giant Panda feces, J. Biosci. Bioeng., 92, 602-608 (2001)

8 ) Aoki, K., Miyamoto, K., Murakami, S., and Shinke, R.: Anaerobic synthesis of extracellular proteases by the soil bacterium Bacillus sp, AM-23: purification and characterization of the enzymes, Soil. Biol. Biochem., 27, 13771382 (1995)

9 ) Yang, J., Shih, I., Tzeng, Y., and Wang, S.: Production and purification of protease from Bacillus subtilis that can deproteinize crustaceans wastes, Enzyme Microbiol. Technol., 26, 406-413 (2000)

10) Kim, Y. K., Bae, J. H., Oh, B. K., Lee, W. H., and Choi, J. W.: Enhancement of proteolytic enzyme activity excreted from Bacillus stearothermophilus for a thermophilic aerobic digestion process, Biores. Technol., 82, 157-164 (2002)

11) Cowan, D. A. and Daniel, R. M.: Purification and some properties of an extracellular protease (caldolysin) from an extreme thermophile, Biochem. Biophys. Acta, 705, 293-305 (1982)

12) Hutadilok, T. N., Painupong, A., and Suntinanalert, P.: Purification and characterization of an extracellular protease from alkaliphilic and thermophilic Bacillus sp. PS719, J. Biosci. Bioeng., 87, 581-587 (1999)

13) Vanugopal, V., Ahr, M., and Nerkar, D. P.: Solubilization of fish proteins using immobilized microbial cells, Biotechnol. Bioeng., 33, 1098-1103 (1989)

14) Nomura, T., Akihara, S., Takai, K., and Sako, Y.: Thermaerobacter nagasakiensis sp., a novel aerobic and extremely thermophilic marine bacterium, Arch. Microbiol., 177, 339-344 (2002)

15) Ghorbel, B., Sellami-Kamoun, A. and Nasri, M.: Stability studies of protease from Bacillus sereus BG1, Enzyme Microbial. Technol., 32, 513-518 (2003)

16) Bomio, M., Sonnleitner, B., and Fiechter, A.: Growth and biocatalytic activities of aerobic thermophilic populations in sewage sludge, Appl. Microbiol. Biotechnol., 32, 356-362 (1989)

17) Kume, S. and Fujio, Y.: Digestion of municipal sewage sludge by a mixture of thermophilic Bacilli and their culture extract, J. Gen. Appl. Microbiol., 36, 189194 (1990)

18) Kole, M. M., Draper, I., and Gerson, D. F.: Production of protease by Bacillus subtilis using simultaneous control of glucose and ammonium concentration, J. Chem. Tech. Biotech., 41, 197-206 (1987)

19) Fox, P. and Pohland, F. G: Anaerobic treatment applications and fundamentals: substrate specificity during phase separation, Water Environ. Res., 66, 716-724 (1994)

20) Mabrouk, S. S., Hashem, A. M., El-Shayeb, N. M. A., Ismail, A.-M. S., and AbdelFattah, A. F.: Optimization of alkaline protease productivity by Bacillus licheniformis ATCC21415, Biores. Technol., 69, 155-159 (1999)

(Submitted 2004. 3. 25)

(Accepted 2004. 6. 3) 